\title{
Review, Comparison, and Outlook of the Influence of International Financial Crisis on Selected Top Universities
}

\author{
Kai Yu*, Yinhan Wang, Qi Yue \\ Shanghai Jiao Tong University, Shanghai, China \\ Email: kyu@sjtu.edu.cn
}

Received 7 August 2014; revised 25 August 2014; accepted 10 September 2014

Copyright (C) 2014 by authors and Scientific Research Publishing Inc.

This work is licensed under the Creative Commons Attribution International License (CC BY). http://creativecommons.org/licenses/by/4.0/

\section{c) (i) Open Access}

\begin{abstract}
The 2008 financial crisis caused severe impact on the world economy. What influences would the challenging economic situation exert on top universities? This paper assesses such influences on five selected top universities. The paper finds that, the financial crisis has had major impact on the endowment of universities, but the endowment payout has been smoothed; with relatively stable research, tuition, and endowment income, private top universities have been less affected than public ones which rely more heavily on state government funding; and that these top universities took relatively moderate measures against the crisis. The paper also discusses the implications of this crisis to the top universities and to the building of top universities.
\end{abstract}

\section{Keywords}

Financial Crisis, Endowment, Public Top Universities, Private Top Universities, University Finance

\section{Background}

In the summer of 2007, the financial crisis triggered by the surge of default cases in the United States subprime mortgage industry spread rapidly from the financial industry to the economy, creating a great impact on the economies of many countries. Within one year, from July 2008 to June 2009, eight top universities in the Ivy League, including Harvard, Yale, and Princeton, lost \$26.6 billion from their endowment fund assets. The University of California system, a prestigious public university system, had a funding gap of \$8130 million and announced that it had entered an "extreme finance emergency condition" due to substantial reductions of state government allocations (Wee, 2009). Harvard University remarked that the loss in endowment funds was sig-

\footnotetext{
*Corresponding author.
}

How to cite this paper: Yu, K., Wang, Y. H., \& Yue, Q. (2014). Review, Comparison, and Outlook of the Influence of International Financial Crisis on Selected Top Universities. Creative Education, 5, 1648-1657. 
nificantly detrimental to Harvard's budget and projects, especially since other primary income channels were challenged by the economic crisis as well (Hechinger \& Karmin, 2008).

How do financial crises influence higher education? Since these top universities lost so much money within one year and were confronted with other challenges in a complex economic environment, were their education and research affected? Will they be descended to second-class universities or even go into bankruptcy? There are concerns about these issues.

The literature includes studies specific to the economic environment of higher education. Windolf (1992) studied the relation between economic growth and the enrollment scale of higher education in five countries from 1870 to 1985 and found that universities tend to expand rapidly during economic recession; that is, the enrollment scale of higher education has a negative relation with economic growth. Frances (1990) also believed that higher education has a counter-cyclical characteristic. However, Froomkin (1990) concluded that the 1980-84 economic recession caused fiscal difficulties for higher education and influenced the normal operations of universities. Economic crises usually reduce government revenue, since an increased unemployment rate results in the growth of government expenses, government support for higher education typically decreases (Johnson, Oliff, \& Williams, 2011). For example, in the United States, the latest international financial crisis created financial difficulties for state governments (National Governors Association \& National Association of State Budget Officers, 2010). A majority of the states reduced spending on higher education or increased tuition fee to cope with insufficient funds. Some universities reduced their enrollment scale, and some even faced the risk of shutting down (Morey, 2004). In addition, the chaos of financial disorder resulted in difficulty in obtaining student loans (Bhaskar \& Gopalan, 2009).

Years have passed since the outbreak of this large-scale international financial crisis, and we can undertake a review of and draw conclusions about its influence on universities. The result of this analysis will increase understanding of the influence of financial crises and provide meaningful resources for the development of top universities in complicated economic environments.

\section{Choice of Universities and Period of Time}

Based on the Times Higher Education ranking and the Academic Ranking of World Universities by Shanghai Jiao Tong University, five top-ranked universities were chosen as the research sample. Considering the obvious differences in income between American and British universities and between private and public universities which resulted in different effects from the financial crisis, this author selected top universities from each category for the sample. Since the attributes which separate private and public British universities are complicated, this research chose one university in the United Kingdom. Private universities in the United States account for the largest share of top universities in the two rankings, and this is reflected in the sample. The sample of selected universities is presented in Table 1.

This article presents findings on the influences of the most recent international financial crisis on these universities. The stock market is used as a barometer for the economy. Figure 1 shows the level of the S \& P 500 Index from 2007 to 2010, which represents trends in the broader U.S. stock markets. Based on this figure, the

Table 1. Five top universities under study.

\begin{tabular}{|c|c|c|c|}
\hline University & $\begin{array}{l}\text { Nation and type } \\
\text { of university }\end{array}$ & $\begin{array}{l}\text { Ranking in world } \\
\text { university rankings } \\
\text { (2010) by the Times } \\
\text { Higher Education }\end{array}$ & $\begin{array}{l}\text { Ranking in the academic } \\
\text { ranking of world } \\
\text { universities (2010) by } \\
\text { Shanghai Jiao Tong University }\end{array}$ \\
\hline Harvard University (Harvard) & Private university in the United States & 1 & 1 \\
\hline $\begin{array}{l}\text { Massachusetts Institute } \\
\text { of Technology (MIT) }\end{array}$ & Private university in the United States & 3 & 4 \\
\hline Yale University (Yale) & Private university in the United States & 10 & 11 \\
\hline $\begin{array}{l}\text { University of California, } \\
\text { Berkeley (Berkeley) }\end{array}$ & Public university in the United States & 8 & 2 \\
\hline University of Cambridge (Cambridge) & Public university in the United Kingdom & 6 & 5 \\
\hline
\end{tabular}




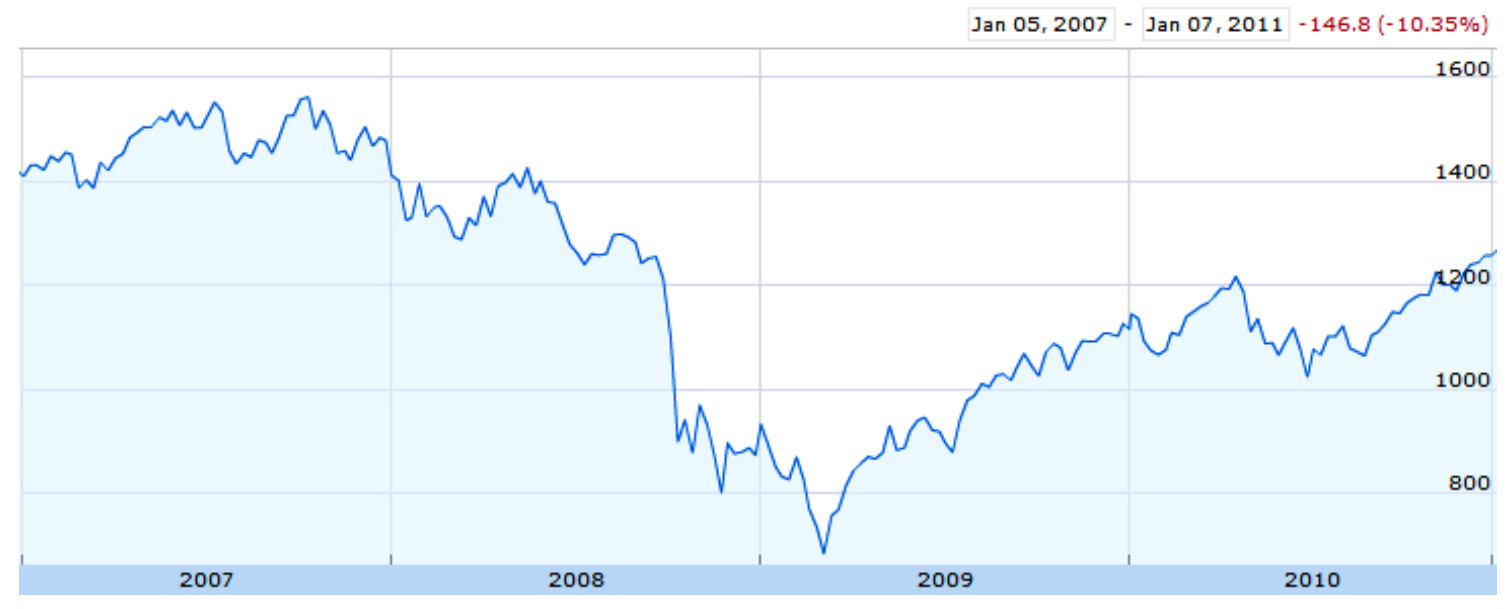

Figure 1. Level of the U.S. S \& P 500 Index, 2007-2010.

latency stage of the financial crisis stretched from mid-2007 to late 2008. In this period, the subprime mortgage and financial crises had begun to ferment; however, their influence on the overall economy was relatively limited. Mid-2008 to mid-2009 marked the outbreak stage of the financial crisis; and its influence was fully felt in the 6\% year-on-year decrease in the United States' GDP from the fourth quarter of 2008 to the first quarter of 2009 (Bureau of Economic Analysis, 2009). The unemployment rate hit 10.1\% in October 2009 for the first time since 1983, and workers' weekly hours decreased to an historic low (Herbst, 2009). From mid-2009 to mid-2010 was regression stage of the financial crisis, when it began to recede and the economy was to revive gradually.

Therefore, the author studied the situation of the sample universities during these three time periods (mid2007 to mid-2008, mid-2008 to mid-2009, and mid-2009 to mid-2010). Data for this article were collected from the universities' annual reports, financial statements, and Common Data Set (CDS). The reporting period for American universities' financial statements matches the time periods selected in this study, i.e., from July 1 of this year to June 30 of the next year. For example, references to "Harvard University in 2008" indicate Harvard's situation from July 1, 2007 to June 30, 2008. However, the reporting period for the University of Cambridge is slightly different, from August 1 this year to July 31 next year. The study reports currency in U.S. dollars. Cambridge's financial data was converted to the U.S. dollar based on the exchange rate of the British pound to U.S. dollar on August 1, 2010.

\section{Study Results}

\subsection{Influence on Overall Finances}

The most direct manifestation of a financial crisis is its influence on the finances of various organizations. The most recent financial crisis influenced universities' finances in three major areas: income, expenses, and their relative balance (i.e., profit or loss). Since the profit-loss balance includes both income and expenses, we examine the influence of the financial crisis only on top universities' relative levels of income and of expenses.

In Table 2, it is seen that, in 2009 when the influence of the financial crisis was most severe, the income of the five top universities did not decrease, on the contrary, increased substantially. In addition, except for Harvard, the universities' income increased again in 2010 compared to that in 2009, although these increases are relatively small. This trend implies that the financial crisis did not exert a serious, negative influence on the universities' overall income.

Income is merely one aspect of finances. Even if income is not seriously affected, the financial crisis could still cause substantial increases in expenses and thus a funding gap for universities. Therefore, it is necessary to investigate the relative levels of income and expense. Table 3 reports the ratio between income and expenses for each university. A value of 1 indicates that income equals expenses, values greater than 1 indicate that income exceeds expenses, and values less than 1 indicate that expenses exceed income. Unlike businesses whose goal is to maximize profit, the optimum financial status for universities, as non-profit institutions, is a balance between income and expenses; i.e., the value should be as close to 1 as possible, with neither a substantial surplus nor a 
Table 2. Variations in income during the financial crisis.

\begin{tabular}{cccc}
\hline & Base level in 2008 & Year-on-year variation in 2009 & Year-on-year variation in 2010 \\
\hline Harvard & $\$ 3.48$ billion & $+9.34 \%$ & $-2.17 \%$ \\
MIT & $\$ 2.40$ billion & $+9.78 \%$ & $+0.72 \%$ \\
Yale & $\$ 2.34$ billion & $+10.78 \%$ & $+4.81 \%$ \\
Berkeley & $\$ 1.78$ billion & $+4.39 \%$ & $+9.36 \%$ \\
Cambridge & $\$ 1.66$ billion & $+6.98 \%$ & $+4.94 \%$ \\
\hline
\end{tabular}

Table 3. Variations in income-expense ratio during the financial crisis.

\begin{tabular}{cccc}
\hline & Income-expense ratio in 2008 & Income-expense ratio in 2009 & Income-expense ratio in 2010 \\
\hline Harvard & 1.01 & 1.01 & 1.00 \\
MIT & 1.05 & 1.07 & 1.12 \\
Yale & 1.01 & 1.04 & 1.06 \\
Berkeley & 0.99 & 0.99 & 1.07 \\
Cambridge & 1.01 & 0.98 & 1.00 \\
\hline
\end{tabular}

substantial deficit. As seen in Table 3, none of the five universities has encountered a substantial financial deficit since the beginning of the financial crisis. Although Berkeley and Cambridge had lower income than expenses in 2009, the differences were within $2 \%$, a reasonable differential. Other universities had much higher income surpluses in 2009 and 2010.

These trends indicate that, after the financial crisis, the income and expenses of top universities are still healthy and have maintained basic balance. Most universities have an income surplus. Generally, the top universities did not generate substantial deficits due to the financial crisis.

\subsection{Influence on Endowment Funds}

Endowment funds to top universities have long performed well in the international financial market, quickly appreciating value. For example, Harvard's average yearly rate of return from its endowment fund was $15.7 \%$ from 1978 to 2008, accumulating \$36 billion by 2008 (Swensen, 2009). However, the 2008 financial crisis hit financial markets severely, monetary assets depreciated greatly, and universities' endowment funds were unavoidably affected. The scale of Harvard's and Yale's endowment funds (including new donations in the same year) declined nearly 30\% in 2009, while those of the MIT and Berkeley dropped approximately 20\%, and Cambridge's $6 \%$ as illustrated in Table 4 . With the gradual fading of the financial crisis and recovery of financial markets, the prices of financial products went up in 2010, and therefore, the value of the universities' endowment funds also rose again.

Although the financial crisis negatively affected the value of endowment funds, accounting for endowment funds is conducted separately from the accounting of the university operations. Therefore, the scale change of an endowment fund is shown only in a separate accounting book and does not directly influence universities' income. Universities' operations are influenced by the amount of funds drawn from endowments to support the universities. For an endowment fund to act as a long-term, stable, predictable income source, universities fomulate policies to smooth expenditures from the endowments. The amount withdrawn annually is usually calculated based on a certain ratio (typically $4.5 \%$ to $6 \%$ ) of the fund's average value over a set period, such as five years.

Table 5 shows that, although universities' endowment funds were hit severely in 2009, the income from the endowment funds did not decline in that year, but instead, rose substantially on the whole. In other words, endowments still provided abundant funds for universities in 2009, mainly because the amount of withdrawals from endowment funds is decided before the beginning of that year. 
Table 4. Change in endowment fund value during the financial crisis.

\begin{tabular}{cccc}
\hline & 2008 base level & 2009 year-on-year basis & 2010 year-on-year basis \\
\hline Harvard & $\$ 36.92$ billion & $-29.49 \%$ & $+5.85 \%$ \\
MIT & $\$ 10.23$ billion & $-21.34 \%$ & $+5.13 \%$ \\
Yale & $\$ 22.84$ billion & $-28.65 \%$ & $+1.97 \%$ \\
Berkeley & $\$ 2.88$ billion & $-18.73 \%$ & $+9.42 \%$ \\
Cambridge & $\$ 1.34$ billion & $-6.21 \%$ & $+13.42 \%$ \\
\hline
\end{tabular}

Table 5. Expense changes in endowment funds during the financial crisis.

\begin{tabular}{cccc}
\hline & 2008 base level & 2009 year-on-year basis & 2010 year-on-year basis \\
\hline Harvard & $\$ 1.20$ billion & $+17.90 \%$ & $-6.76 \%$ \\
MIT & $\$ 0.45$ billion & $+32.39 \%$ & $-14.23 \%$ \\
Yale & $\$ 0.84$ billion & $+36.80 \%$ & $-5.04 \%$ \\
Berkeley & $\$ 0.09$ billion & $+13.55 \%$ & $+5.69 \%$ \\
Cambridge & $\$ 0.05$ billion & $+3.70 \%$ & $+0.60 \%$ \\
\hline
\end{tabular}

Although the financial crisis in 2009 made the scale of endowment funds shrink on an average of more than $20 \%$, Harvard, MIT, and Yale's income from their endowments in 2010 decreased no more than $10 \%$ on average. When expenditures were drawn, the smoothed expense was based on the average value of the fund over the past few years instead of only last year, buffering against short-term fluctuations in financial markets. In addition, to ensure normal operations, universities could choose to temporarily increase the fund's expense ratio to maintain the expenditure at an absolute level amid a decrease in the fund scale. Therefore, despite the sharp decline of fund scales in 2009, the decline in expenditures in 2010 was much more moderate. However, the smoothing expense method also meant that the sharp decrease in the fund scale in 2009 had negative effects on universities' endowment fund expenditures in the future. For example, Yale's loss of endowment funds in 2009 will result in an annual funding gap of \$150 million from 2011 to 2014 (Staley \& Lorin, 2010). However, given the quick recovery of fund value after the financial crisis, that funding gap is not exceedingly high for Yale, whose annual operating expenditures exceed $\$ 2.7$ billion and whose endowment fund totals at $\$ 16.6$ billion.

\subsection{Influence on Primary Income}

The data so far show that the financial crisis did not have a significant influence on the overall income of top universities or cause severe income shortages. As universities have different income sources and channels, it is worth studying the crisis' influence on these different income channels.

First are government grants, specifically non-competitive, general-education grants. U.S. private universities receive no governmental allocations (but can receive substantial competitive research funding, which is discussed later), therefore there is no government grants for them. U.S. public universities receive allocations from state governments, while the majority of U.K. universities receive government grants disbursed by the Higher Education Funding Council. In Table 6, Berkeley's income refers to grants from the state government, and Cambridge's to grants from the Higher Education Funding Council of England. Berkeley's state grant decreased nearly 30\% in 2009 when hit by the financial crises and fell again in 2010. The downward trend continued: In January 2011, the new governor of California proposed lowering 17\% of the government grant for the University of California system (Keller, 2011). Berkeley's situation was similar to that of most U.S. public universities, only the cuts from its government grants were proportionally higher because California was hit severely by the financial crisis. For example, the state government grant for the University of Michigan, another prestigious public university, declined 7\% in 2009 from 2008, followed by 6\% down in 2010 (University of Michigan, 2010).

Although state government grants dropped sharply from 2009 to 2010, the U.S. federal government offered 
Table 6. Change in government grants during the financial crisis.

\begin{tabular}{cccc}
\hline & 2008 base level & 2009 year-on-year basis & 2010 year-on-year basis \\
\hline Berkeley & $\$ 450$ million & $-29.13 \%$ & $-0.20 \%$ \\
Cambridge & $\$ 316$ million & $+1.49 \%$ & $+0.15 \%$ \\
\hline
\end{tabular}

extra grants to public universities through state governments under the economic stimulation package of the American Recovery and Reinvestment Act (ARRA). For example, Berkeley gained \$51.24 million in economic stimulus funding from the federal government in 2009 , equivalent to $16 \%$ of the general education grant from the state government, to some extent relieving the influence of the state government cutbacks. Although the absolute amount of Cambridge's government grant did not decrease during the financial crises, the growth rate was extremely low. If inflation is taken into account, the actual value of the government grant declined slightly from 2009 to 2010.

Indeed, the shrinking contribution to total income from government grants has been a long-term trend faced by most leading public universities in the U.S., a trend only accelerated by the financial crisis' impact on state governments. Most top public universities have anticipated this trend and made adjustments to reduce their reliance on government grants. For example, with the gradual lowering of state government grants and raising of tuition fee since early 2009, Berkley's annual income from tuition has surpassed that from the state general education grant. In 2010, government grants accounted for only 15.6\% of Berkley’s income and 17.2\% of Cambridge's.

Tuition is also an important income source for top universities. Table 7 shows that income from tuition for three private U.S. universities declined in 2009, but for the public universities such as Berkeley and Cambridge, it increased more sharply in 2009 than that in 2010. Income from tuition is affected by many factors, including the number of students, student structure (different charges for different types of students), tuition fee standards, and exemption amounts.

The data show that the financial crisis had inconsistent effects on the tuition income of different universities. The tuition incomes of private, top U.S. universities which already charged high fees underwent no significant changes, but the percentage of income derived from tuition for less expensive, top public universities in the U.S. and U.K. went up. For example, to reduce the funding gap caused by sharp cuts from government grants, Berkeley took such measures as raising tuition fee to increase income (University of California, 2009). The increase of tuition at private universities was more moderate, because as they raised tuition fee, they also increased scholarships, and therefore, income from tuition did not change significantly.

Research is an important function of top universities, and research income serves as a main income channel, drawing from sources such as governments, non-government and charity organizations, and enterprises. Table $\mathbf{8}$ shows that the research income of top universities was not affected negatively by the financial crisis. The research income for all five universities maintained at a high growth rate in 2009 and 2010 because governments, charity organizations, and enterprises did not reduce research funding for universities. In fact, the ARRA economic stimulus package created additional competitive research funding sources. Top universities in the U.S. competed for these national funding and actually increased their research income during the financial crisis.

The funds which universities acquire from different channels often have different, specified purposes. For example, donors may dictate that their donation be used only to fund scholarships in a certain institute or to endowed teaching professorships and may not be used for other purposes, which limited universities' ability to allocate income during the financial crisis. In the U.S. and U.K., research funds usually cover both direct and indirect costs, therefore the steady increase of research funds strengthens universities' ability to allocate funds.

\subsection{Influence on Teachers}

For top universities, human resources are expensive and staff expenses account for up to half of total operating expenses. Table 9 shows the five selected universities' staff expenses during the financial crisis, including salary, benefits, and insurance. Staff expenses for the five universities did not decrease in 2009 when the financial crisis broke out. However, in 2010, they fell or only grew slightly for three universities and increased at Cambridge. Data for Yale were not available. 
Table 7. Changes in income from tuition during the financial crisis.

\begin{tabular}{cccc}
\hline & 2008 base level & 2009 year-on-year basis & 2010 year-on-year basis \\
\hline Harvard & $\$ 681$ million & $-0.53 \%$ & $4.94 \%$ \\
MIT & $\$ 229$ million & $-5.11 \%$ & $9.62 \%$ \\
Yale & $\$ 245$ million & $-6.47 \%$ & $-1.89 \%$ \\
Berkeley & $\$ 331$ million & $+9.32 \%$ & $+13.77 \%$ \\
Cambridge & $\$ 127$ million & $+13.58 \%$ & $+10.87 \%$ \\
\hline
\end{tabular}

Table 8. Changes in competitive research funding during the financial crisis.

\begin{tabular}{cccc} 
& 2008 base level & 2009 year-on-year basis & 2010 year-on-year basis \\
\hline Harvard & $\$ 668$ million & $+6.76 \%$ & $+8.85 \%$ \\
MIT & $\$ 1.24$ billion & $+10.43 \%$ & $+12.04 \%$ \\
Yale & $\$ 561$ million & $+4.92 \%$ & $+8.88 \%$ \\
Berkeley & $\$ 543$ million & $+6.93 \%$ & $+12.76 \%$ \\
Cambridge & $\$ 363$ million & $+12.07 \%$ & $+2.96 \%$ \\
\hline
\end{tabular}

Note: The Broad Institute of MIT undertook independent accounting starting 2010, therefore it is not included in 2010.

Table 9. Change in staff expenses during the financial crises.

\begin{tabular}{cccc}
\hline & $\mathbf{2 0 0 8}$ base level & $\mathbf{2 0 0 9}$ year-on-year basis & 2010 year-on-year basis \\
\hline Harvard & $\$ 1.66$ billion & $+10.84 \%$ & $-2.78 \%$ \\
MIT & $\$ 1.06$ billion & $+6.61 \%$ & $+1.00 \%$ \\
Yale & $\$ 1.33$ billion & $+7.75 \%$ & No Data \\
Berkeley & $\$ 1.13$ billion & $+5.02 \%$ & $-1.55 \%$ \\
Cambridge & $\$ 0.73$ billion & $+9.58 \%$ & $+6.21 \%$ \\
\hline
\end{tabular}

During the financial crisis, many universities took such measures as suspending raises and expanding of personnel scale. For example, in 2010, Harvard delayed salary increases, greatly reduced bonus payments, slowed the pace of new staff recruitment, and encouraged early retirements. Yale suspended salary raises for high-income staff, including administrators and the director of the university (Harvard University, 2009). However, universities also froze hiring in administrative and subsidiary departments. For example, in 2009, Harvard cut 275 administrative and subsidiary positions to improve operational efficiency (Harvard University, 2009). However, that number is not significant compared to the total of more than 13,000 administrative and subsidiary employees, and no faculty members were dismissed. Of 21,000 staff members, Berkeley cut approximately 500 positions in 2009 and 2010 and another 150 in 2011. However, no full-time teachers were affected. The layoffs are part of long-term plans to increase efficiency and control expenses (Harvard University, 2009). These actions also show that top universities regarded full-time teachers as valuable human resources and did their best to avoid cutting full-time teaching positions when faced by demand to lower personnel expenses. The University of California system was affected more severely. Since 2009, the system has implemented an unpaid leave policy which has required 108,000 of 135,000 full-time staff members to accept 11 to 26 days of unpaid leave, equivalent to $4 \%$ to $10 \%$ salary reduction (University of California, 2009).

\subsection{Influence on Students}

The financial crisis could affect the number of full-time students and applicants and the amount of tuition and scholarships. Students' greatest concern is whether the financial crisis will prompt universities to increase tuition fee. Table 10 presents the tuition for undergraduate students at five top universities during the financial crisis. 
Table 10. Changes in tuition fees during the financial crisis.

\begin{tabular}{cccc}
\hline & 2008 base level & 2009 year-on-year basis & 2010 year-on-year basis \\
\hline Harvard & $\$ 31,456$ & $+3.50 \%$ & $+3.50 \%$ \\
MIT & $\$ 34,750$ & $+4.00 \%$ & $+3.79 \%$ \\
Yale & $\$ 34,530$ & $+2.23 \%$ & $+3.40 \%$ \\
Berkeley & $\$ 8384$ & $+6.54 \%$ & $+15.69 \%$ \\
Cambridge & $\$ 4933$ & $+2.54 \%$ & $+2.02 \%$ \\
\hline
\end{tabular}

Berkley's tuitions are those of the University of California system, and those of Cambridge refer to tuition level for British and European Union students.

Harvard, MIT, and Yale increased tuition fees slightly and steadily in 2009 and 2010 at a rate nearly the same as before the financial crisis (Ehrenberg, 2002). Therefore, tuition did not change due to the financial crisis. Berkeley's tuition fee rose sharply in both 2009 and 2010 due to dramatic cuts from state government grants, one of its main income sources. The university raised tuition fees to increase income and make up for the funding gap. Before 2012, Cambridge was legally required to maintain fixed fees, adjusted annually only for inflation and, therefore, keeps tuition unchanged after accounting for inflation.

The financial crisis had no significant effect on the number of students at top universities. Although the director of Berkeley proposed admitting fewer students (Keller, 2011), that plan has not been put into effect. Neither has the financial crisis reduced applicants' enthusiasm for top universities. The number of applicants to the five universities (no data were available for Harvard for 2010) in 2009 and 2010 increased by a large margin compared to those in 2008. However, the number of applicants to Berkeley in 2010 only equaled the number in 2009, perhaps due to the sharp increase in tuition fees. In addition, keeping in mind the lack of data for Cambridge, the financial crisis did not have a negative impact on the scholarship of the top universities as a whole, and their total expenses in 2009 and 2010 remained stable.

\section{Conclusion and Discussion}

This paper reviewed and compared the international financial crisis's various influences on five top universities. The conclusions are as follows.

The financial crisis seriously influenced the endowment funds of top universities. However, the smoothed spending from endowment funds moderated that influence. Through endowment funds, top universities participate in investments in financial products, and depreciation of these products unavoidably affects the value of endowment funds. Universities lost nearly $30 \%$ of their endowments in 2009, and hundreds of billions of dollars in market value were lost during the crisis. However, since the function of smoothing was included in the policy design for endowment fund and the financial market quickly recovered, the sharp decline in endowment funds' value had only a moderate negative impact on the operation of universities, despite their great dependence on income from endowment funds.

Relatively, the financial crisis had more serious impacts on U.S. public universities which are dependent on state governments and less on private universities which rely on a mixture of stable research revenue, tuition, and donations. Among the five selected top universities, Berkeley was affected most because it is dependent on government grants most. When the financial crisis caused huge disruptions to local governments' finances, the California state government, which regarded higher education spending as discretionary (NCSL Fiscal Affairs Program, 2010), sharply reduced appropriations to universities, creating a large funding gap for public universities. However, by raising tuition, competing for research funds, and controlling expenses, Berkeley still maintained its financial health. Amid drastic cuts from government grants, universities posted large balances in 2010. During the financial crisis, the research funds offered by the U.S. federal government, non-profit organizations, and enterprises did not fall; nor did the British government grants to universities. Combined with stable income from tuition and spending from endowment funds after smoothing policies, these factors prevented many negative impacts on the operation of private and British top universities. It is worth noting that since 2012, the British government has sharply raised tuition fee and cut grants to universities, which will result in a rapid increase of tuition income and universities' total income and in a decline in government grants, possibly having a huge im- 
pact on U.K. universities. However, this policy change is part of a long-term plan, not a direct result of the financial crisis.

Top universities took only moderate measures to deal with the financial crisis. These measures included controlling expenses and increasing income. To control expenses, many top universities took such steps as suspending salary raises, reducing employment recruitment, cutting supporting positions, encouraging early retirements, promoting cooperating among all departments, unifying procurement, and suspending major capital investments to save operational costs (Wee, 2009). Only severely affected universities chose to impose unpaid leave on staff. Some measures were part of long-term cost-control plans, which universities would have implemented even without the financial crisis. Compared to the measures taken by enterprises to dismiss staff and even declare bankruptcy due to financial crisis, such efforts were relatively gentle. To increase income, all the top universities with abundant endowment funds chose to moderately increase spending from endowments. In addition, the financial crisis had some positive impacts on universities. For example, some universities applied for loans to take advantage of low interest rates during the crisis, and made savings on long-term operating costs (Wee, 2009).

In addition, this research found that part of the influences caused by financial crisis had a lagging effect. Although the crisis broke out in 2008 to 2009, many of its impacts on universities lagged behind one year and were reflected only in 2009 to 2010. Endowment funds' value is connected closely to the market and reflects market fluctuations. Therefore, the financial crisis' impact on endowments appeared immediately. However, universities' budgets and operation plans, including staff expenses, allocation, spending from donations and admissions, are all scheduled in advance or require a longer process for decision-making and implementation. In other words, a time lag for the financial crisis' impact on the university exists. Therefore, researchers studying the impact of the crisis should observe from a longer period of time, rather than only the year the crisis broke out.

Modern universities have been integrated into the economy, so changes in economic conditions unavoidably have impact on universities. However, according to this study, the international financial crisis generally did not seriously affect the normal operation of top universities, despite the significant impact on economic order. Most universities coped with the financial crisis by taking only moderate measures to control expenditures and increase income. Even top, public U.S. universities which endured relative serious effects could survive safely. The conditions of top universities, however, do not represent those of all universities. Those which lack of research funds and good management of endowment funds will be more severely affected by the large cut from government grants (Moody's, 2011).

During the five or six years before the financial crisis broke out, favorable economic conditions and rapidly increasing endowments created a golden age of development for top universities, especially for private U.S. universities. The financial crisis halted the rapid growth that top universities had maintained for a number of years. However, with the rapid economic recovery, revitalization of growth has begun. In early 2011, Standard \& Poor's 500 Index returned to its highest level in the past two years, and a consensus was reached that the world economy had entered full recovery mode. Under these conditions, the value of top universities' endowments will also recover quickly. Therefore, the financial crisis acted more like half-time break in the development of top universities, rather than a terminal or turning point. During short-term recessions, top universities, especially public U.S. universities, should re-consider their development mode, absorb lessons from financial crises, and take the best path for long-term development. The development of top universities during the international financial crisis vividly demonstrates the importance of a diversified income structure, stable financial grants, solid endowment fund, and an excellent system design to ensure a university's effective response to a complex economic environment.

\section{Acknowledgements}

"Chen Guang” project is supported by Shanghai Municipal Education Commission and Shanghai Education Development Foundation.

\section{References}

Bhaskar, R., \& Gopalan, Y. (2009). As College Costs Rise, Student Loans Are Harder to Find. Inside the Vault, 13.

Bureau of Economic Analysis (2009). National Income and Product Accounts.

http://www.bea.gov/newsreleases/national/gdp/gdpnewsrelease.htm

Ehrenberg, R. G. (2002). Tuition Rising: Why College Costs So Much. Cambridge, MA: Harvard University Press. 
Frances, C. (1990). Key Economic Indicators for Higher Education. In K. H. Hanson, \& J. W. Meyerson (Eds.), Higher Education in a Changing Economy. New York: American Council on Higher Education and Macmillian.

Froomkin, J. (1990). Impact of Changing Financial Resources. Albany, NY: SUNY Press.

Harvard University (2009). Financial Report Fiscal Year 2009. Cambridge, MA: Harvard University.

Hechinger, J., \& Karmin, C. (2008). Harvard Hit by Loss as Crisis Spreads to Colleges. The Wall Street Journal.

Herbst, M. (2009). Unemployed Lose with Hour and Wage Cuts. BusinessWeek.

Johnson, N., Oliff, P., \& Williams, E. (2011). An Update on State Budget Cuts: At Least 46 States Have Imposed Cuts That Hurt Vulnerable Residents and the Economy. Washington, D.C.: Center on Budget and Policy Priorities.

Keller, J. (2011). California’s Public Colleges Face \$1.4-Billion in New Budget Cuts. Chronicle of Higher Education.

Moody’s (2011). 2011 Outlook for U.S. Higher Education. New York: Moody’s Investors Service.

Morey, A. I. (2004). Globalization and the Emergence of For-Profit Higher Education. Higher Education, 48, 131-150. http://dx.doi.org/10.1023/B:HIGH.0000033768.76084.a0

National Governors Association, \& National Association of State Budget Officers (2010). The Fiscal Survey of States, June 2010. Washington DC: National Association of State Budget Officers.

NCSL Fiscal Affairs Program (2010). State Funding for Higher Education in FY 2009 and FY 2010. Washington DC: National Conference of State Legislatures.

Staley, O., \& Lorin, J. F. (2010). Yale Makes \$50 Million Budget Cut, Seeks More Savings. BusinessWeek.

Swensen, D. F. (2009). Pioneering Portfolio Management: An Unconventional Approach to Institutional Investment, Fully Revised and Updated. Florence, MA: Free Press.

University of California (2009). Regents Approve Fiscal Plan, Furloughs. Oakland, CA: University of California.

University of Michigan (2010). Financial Report 2010. Ann Arbor, MI: University of Michigan.

Wee, G. (2009). Endowment Losses from Harvard to Yale Force Cuts. Bloomberg.

Windolf, P. (1992). Cycles of Expansion in Higher Education 1870-1985: An International Comparison. Higher Education, 23, 3-19. http://dx.doi.org/10.1007/BF00141141 
Scientific Research Publishing (SCIRP) is one of the largest Open Access journal publishers. It is currently publishing more than 200 open access, online, peer-reviewed journals covering a wide range of academic disciplines. SCIRP serves the worldwide academic communities and contributes to the progress and application of science with its publication.

Other selected journals from SCIRP are listed as below. Submit your manuscript to us via either submit@scirp.org or Online Submission Portal.
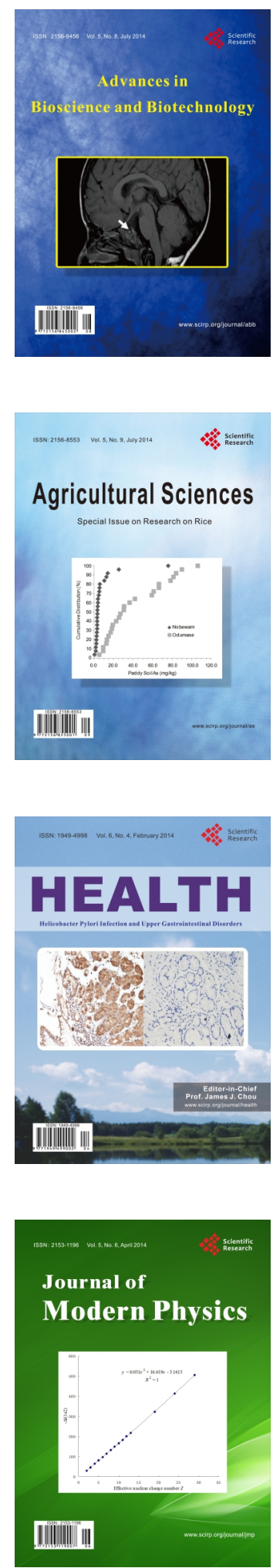
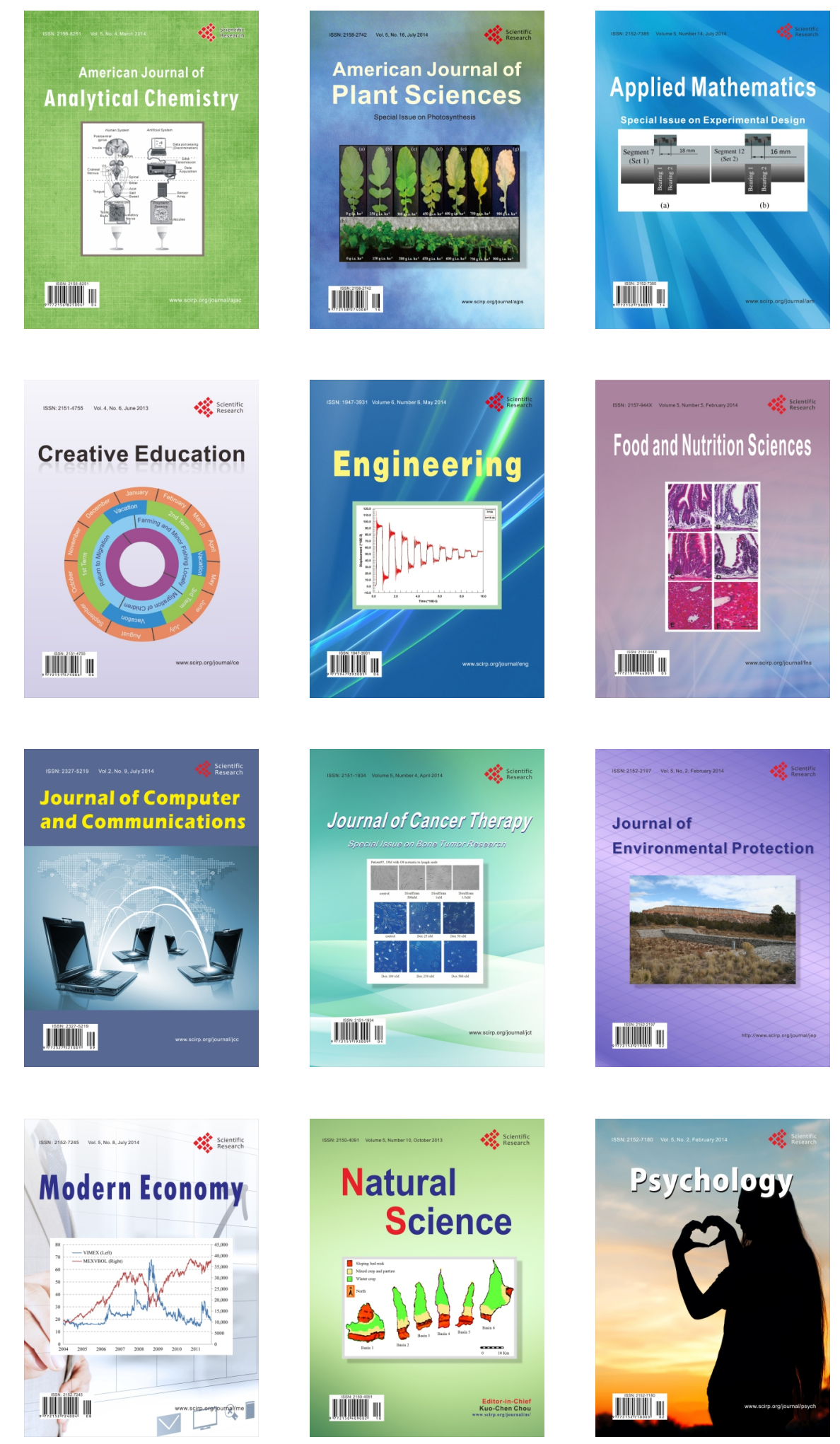